\title{
Correction to: Polinton-like viruses are abundant in aquatic ecosystems
}

Christopher M. Bellas ${ }^{*}$ and Ruben Sommaruga

Correction to: Microbiome 9, 13 (2021)

https://doi.org/10.1186/s40168-020-00956-0

Following publication of the original article [1], it has been reported that reference 5 author group was incorrectly captured.

Reference 5 is currently captured as:

Fischer MG, C a S. A virophage at the origin of large DNA transposons. Science. 2011;332:231-4.

Reference 5 should be captured as:

Fischer MG, Suttle CA. A virophage at the origin of large DNA transposons. Science. 2011;332:231-4.

The original article [1] has been corrected.

Published online: 27 January 2021

\section{Reference}

1. Bellas CM, Sommaruga R. Polinton-like viruses are abundant in aquatic ecosystems. Microbiome. 2021;9:13. https://doi.org/10.1186/s40168-02000956-0.

The original article can be found online at https://doi.org/10.1186/s40168020-00956-0.

* Correspondence: Christopher.bellas@bristol.ac.uk

Department of Ecology, University of Innsbruck, Technikerstrasse 25, A-6020 Innsbruck, Austria

(c) The Author(s). 2021 Open Access This article is licensed under a Creative Commons Attribution 4.0 International License, which permits use, sharing, adaptation, distribution and reproduction in any medium or format, as long as you give appropriate credit to the original author(s) and the source, provide a link to the Creative Commons licence, and indicate if changes were made. The images or other third party material in this article are included in the article's Creative Commons licence, unless indicated otherwise in a credit line to the material. If material is not included in the article's Creative Commons licence and your intended use is not permitted by statutory regulation or exceeds the permitted use, you will need to obtain permission directly from the copyright holder. To view a copy of this licence, visit http://creativecommons.org/licenses/by/4.0/. The Creative Commons Public Domain Dedication waiver (http://creativecommons.org/publicdomain/zero/1.0/) applies to the data made available in this article, unless otherwise stated in a credit line to the data. 